\title{
Interactions between plant-derived oestrogenic substances and the mycoestrogen zearalenone in a bioassay with MCF-7 cells
}

\author{
S. Hessenberger ${ }^{1}$, K. Botzi ${ }^{1}$, C. Degrassi ${ }^{1}$, P. Kovalsky ${ }^{2}$, C. Schwab ${ }^{2}$, \\ D. Schatzmayr' ${ }^{1}$ G. Schatzmayr ${ }^{1}$, J. Fink-Gremmels ${ }^{3}$ \\ ${ }^{1}$ Biomin Research Center, Technopark 1, 3430 Tulln, Austria \\ ${ }^{2}$ Biomin Holding GmbH, Erber Campus 1, 3131 Getzersdorf, Austria \\ ${ }^{3}$ Institute for Risk Assessment Sciences, Faculty of Veterinary Medicine, \\ Utrecht University, Yalelaan 104, 3584 CM Utrecht, The Netherlands
}

\begin{abstract}
Human and animal diets may contain several non-steroidal oestrogenic compounds which originate either from plants (phytoestrogens) or from fungi that infect plants (mycoestrogens such as zearalenone (ZEN)). Phytoestrogens may compete with ZEN in binding to the oestrogen receptor $\beta$ and thereby may counteract the oestrogenic activity of ZEN. Using a modified version of the E-screen assay, plant-derived oestrogenic substances were tested for their proliferative or anti-proliferative effect on oestrogen-dependent MCF-7 cells. The samples were additionally tested for their ability to influence the oestrogenic activity of ZEN $(1 \mu \mathrm{M})$. Among the individual substances tested, 8-prenylnaringenin had the strongest effect, as cell proliferation was increased by $78 \%$ at the lowest concentration $(0.23 \mu \mathrm{M})$, and by $167 \%$ at the highest concentration $(29.4 \mu \mathrm{M})$. Coumestrol $(5.83 \mu \mathrm{M})$ increased cell proliferation by $39 \%$, and genistein $(370 \mu \mathrm{M})$ by $61 \%$, respectively. Xanthohumol and enterolactone did not stimulate cell proliferation significantly. In the co-incubation experiments with ZEN, none of the single substances was able to decrease the oestrogenic activity of ZEN. Only for 8-prenylnaringenin $(14.7$ and $29.4 \mu \mathrm{M})$ was a trend towards an increase in the ZEN-induced cell proliferation up to $72 \%$ observed. In conclusion, with the exception of 8-prenylnaringenin, no substantial interaction between phytoestrogens and the mycotoxin ZEN could be detected using a bioassays with MCF-7 cells.
\end{abstract}

Key words: E-screen assay, oestrogen receptor, mycoestrogen, phytoestrogens, zearalenone

\section{Introduction}

Zearalenone (ZEN) is a resorcylic acid lactone (Urry et al. 1966) produced by several Fusarium species and is commonly found worldwide in cereal grains intended for food and feed (Schatzmayr and Streit 2013). In farm animals, the ingestion of ZEN-contaminated feed can lead to alterations of the reproductive tract, disturbance of the oestrous cycle and decreased fertility due to malfunction of the ovary

Correspondence to: S. Hessenberger, e-mail: sabine.hessenberger@biomin.net, tel.: +432272811660 
(Gajecki 2002, Fink-Gremmels and Malekinejad 2007, Malekinejad et al. 2007, Tiemann and Danicke 2007, Zinedine et al. 2007, Minervini and Dell'Aquila 2008, Doll and Danicke 2011). These effects ultimately lead to lower performance. Pigs are particularly sensitive to ZEN (EFSA 2011). In this species, even very low concentrations of ZEN may lead to hyperoestrogenic syndrome (Gajecka et al. 2012, Schoevers et al. 2012).

ZEN and its derivatives are the only known mycoestrogens and exhibit oestrogenic activity due to the structural resemblance of $17 \beta$-oestradiol (E2), the main hormone produced by the mammalian ovary. ZEN competes with E2 for the specific binding sites of the oestrogen receptors (ER) $\alpha$ and $\beta$ in mammalian target cells (Kuiper-Goodman et al. 1987). E2 binds to ER $\alpha$ via its aromatic ring. However, the volume of the binding cavity of the receptor is almost twice as large as E2, which could allow other compounds with a comparable 3-dimensional structure, such as ZEN and various non-steroidal phytoestrogens, to bind simultaneously (Brzozowski et al. 1997, Jungbauer and Medjakovic 2014, Leclercq and Jacquot 2014). ER $\alpha$ and ER $\beta$ are assumed to have different and even opposing biological functions (Lindberg et al. 2003). ER $\alpha$ seems to play a predominant role in cell proliferation (Pearce and Jordan 2004), while ER $\beta$ may negatively regulate cell proliferation, and has a protective role for example in normal breast cells (Hilakivi-Clarke et al. 2002). When the same cell is co-exposed to multiple agonists, ER $\beta$ inhibits $E R \alpha$-mediated gene expression (Matthews and Gustafsson 2003, Paruthiyil et al. 2011).

The human breast cancer cell line MCF-7 expresses both types of oestrogen receptors with a predominance of $\mathrm{ER} \alpha$ (Nadal-Serrano et al. 2013). MCF-7 cells are very sensitive to oestrogenic compounds and cell proliferation depends on the presence of oestrogen-receptor agonists. This sensitivity facilitated the development of the E-screen assay (Soto et al. 1992) which measures oestrogen-induced proliferation of MCF-7 cells. As demonstrated in transfected MCF-7 cells, E2 is able to activate both ER isomers with similar potency (Harris et al. 2005). Phytoestrogens on the other hand show differential binding to the two ER subtypes, with preference for ER $\beta$ (Leclercq and Jacquot 2014). Therefore, phytoestrogens are presumed to inhibit excessive cell proliferation, for example in hormone dependent breast cancer cells (Ramanathan and Gray 2003, Rietjens et al. 2013). The mycoestrogen ZEN induces proliferation of MCF-7 cells by binding preferentially to ER $\alpha$ (Wang et al. 2010). Phytoestrogens which bind preferentially to the oestrogen receptor ER $\beta$ may counteract the oestrogenic activity of ZEN.
Such an effect was shown for GEN, which repressed the proliferative activity of ZEN on MCF-7 cells (Wang et al. 2010).

Human and animal diets may contain several non-steroidal phytoestrogens which can be classified into: (1) flavonoids such as genistein (GEN), 8-prenylnaringenin (8-PN) or xanthohumol (XAN), (2) coumestans such as coumestrol (COU), and (3) lignans such as precursors for enterolactone (ENT), or cubebin (Nikov et al. 2000). GEN is a natural compound of soybeans (Glycine max L.) or red clover (Trifolium pratense L.). It has been reported that GEN has oestrogenic, anti-oxidative, and anti-inflammatory effects (Record et al. 1995, Hsieh et al. 1998, Danciu et al. 2012, Russo et al. 2016). GEN binds to ER $\alpha$ and ER $\beta$, but has a stronger affinity to ER $\beta$ (Kuiper et al. 1998, Mueller et al. 2004). The flavonoids 8-PN and XAN occur in hop plants $(\mathrm{Hu}$ mulus lupulus $\mathrm{L}$.). Its constituent 8-PN is considered the most potent phytoestrogen isolated to date and binds to ER $\alpha$ and ER $\beta$ (Milligan et al. 2002, Blanquer-Rossello et al. 2013, Busch et al. 2015). XAN is less potent than 8-PN, and is known to exhibit anti-carcinogenic properties and to prevent initiation and progression of cancer (Gerhauser et al. 2002, Deeb et al. 2010, Yoshimaru et al. 2014). XAN seems to inhibit the proliferation of ER $\alpha$-positive breast cancer cells through suppression of the E2-signalling pathways (Blanquer-Rossello et al. 2013, Yoshimaru et al. 2014). COU is a representative of the coumestan group which naturally occurs in broccoli (Brassica oleracea L.), red clover sprouts, alfalfa sprouts (Medicago sativa L.), and soy beans (Adams 1995, Harris et al. 2005). Like GEN, COU binds to $\mathrm{ER} \alpha$ and $\mathrm{ER} \beta$, but has a stronger affinity to ER $\beta$ (Kuiper et al. 1998, Mueller et al. 2004). Oestrogenic effects of COU were shown in different assays in MCF-7 cells (Matsumura et al. 2005). ENT is a member of the lignan group, present in plant foods and human biological fluids. The conversion of plant lignans (secoisolariciresinol and matairesinol) to mammalian lignans (enterodial and ENT) occurs in the gastrointestinal tract as a result of bacterial action (Kurzer and $\mathrm{Xu}$ 1997). Oilseeds, such as flaxseed (Linum usitatissimum L.) and unhulled soybeans, are the richest plant sources of lignans. Anti-oestrogenic effects of flaxseed and its lignans were shown by Bergman Jungestrom (2007).

In the present study, the effect of plant-derived oestrogenic substances on the proliferation of MCF-7 cells and the interaction of the samples with ZEN were tested using a modified version of the E-screen assay. The aim was to assess if these samples are able to alter the oestrogenic effect of ZEN. 
Table 1. Information concerning plant-derived substances tested for their effect on proliferation of oestrogen-sensitive MCF-7 cells.

\begin{tabular}{lccc}
\hline \multicolumn{1}{c}{ (Phyto)estrogen } & Abbreviation & Group & Stock [mM] \\
\hline 8-prenylnaringenin & 8 -PN & Flavonoid & 29.4 \\
Xanthohumol & XAN & Flavonoid & 282 \\
Genistein & GEN & Flavonoid & 370 \\
Coumestrol & COU & Coumestan & 373 \\
Enterolactone & ENT & Lignan & 168 \\
\hline
\end{tabular}

\section{Materials and Methods}

\section{Preparation of samples tested for their effect on MCF-7 cell proliferation}

The samples that were tested in this study are summarised in Table 1. The phytoestrogens and enterolactone were purchased from Sigma-Aldrich (Vienna, Austria). Stocks of all substances were prepared in dimethyl sulfoxide (DMSO; cell culture tested; Sigma-Aldrich) as indicated in Table 1 and finally diluted by a factor of at least 1000 with assay medium (composition is defined in the "Proliferation assay" section). A $63 \mathrm{mM}$ stock of ZEN (Romer Labs ${ }^{\circledR}$, Tulln, Austria) was also prepared in DMSO and diluted with assay medium to the different working concentrations described below. The maximum concentration of DMSO was $0.1 \%$ in all assays.

\section{Cell line and cell culture conditions}

The human breast adenocarcinoma cell line MCF-7 (Number ACC 115) was obtained from the German Collection of Microorganisms and Cell Cultures (DSMZ, Braunschweig, Germany). The cells were routinely grown in a culture medium containing RPMI 1640 supplemented with $10 \%$ foetal bovine serum (FBS), $200 \mathrm{mM}$ L-glutamine, $100 \mathrm{mM}$ sodium pyruvate, and $1 \%$ of the growth supplement ITS (insulin/transferrin/selenium). The cells were maintained under standard conditions at $37^{\circ} \mathrm{C}$ in an atmosphere of $5 \% \mathrm{CO}_{2}$ and saturating humidity. The cells were grown to $90 \%$ confluence and were sub-cultured every 2-3 days using a solution of $0.25 \%$ trypsin and $0.5 \mathrm{mM}$ EDTA (Sigma-Aldrich) for detachment. Unless otherwise stated, all medium components were obtained from PAA Laboratories GmbH (Pasching, Austria).

\section{Proliferation assay}

The proliferation assay was performed according to the E-screen assay described by Soto et al. (1992) with minor modifications. Initially, the proliferative effect of ZEN was tested in a concentration range between 15.6-2000 $\mathrm{nM}$ in the MCF-7 cells to determine the working concentration for the main experiments. To this end, MCF-7 cells were seeded in 96-well plates at an initial concentration of $1 \times 10^{4}$ cells per well in $200 \mu \mathrm{L}$ of culture medium. Cells were allowed to attach for $24 \mathrm{~h}$. The culture medium was thereafter replaced by assay medium, which was composed of culture medium without phenol red, supplemented with $10 \%$ double charcoal-stripped FBS, to exclude any oestrogenic substances in the culture medium. The cells were further cultivated for $2 \mathrm{~h}$ under these conditions, before the medium was discarded and replaced with $200 \mu \mathrm{L}$ of medium containing the different concentrations of ZEN. Cells in assay medium without ZEN served as control. After 6 days of incubation, the medium was discarded and cell proliferation was determined by addition of $100 \mu \mathrm{L}$ of $10 \%$ water soluble tetrazolium-1 (WST-1; Roche Diagnostics, Vienna, Austria) in assay medium. WST-1 is cleaved enzymatically to formazan by cellular mitochondrial dehydrogenase present in all viable cells. The absorbance of the formazan dye produced can be measured at $450 \mathrm{~nm}\left(\mathrm{~A}_{450 \mathrm{~nm}}\right)$, and is directly correlated to the number of viable cells. The first measurement was done immediately after the addition of the WST-1 dye using a GENios microplate reader from Tecan (Grödig, Austria). The cells were then incubated with WST- 1 at $37^{\circ} \mathrm{C}$ in an atmosphere of $5 \% \mathrm{CO}_{2}$ and saturating humidity. The absorbance was measured at regular intervals. The incubation was terminated as soon as the control cells reached an absorbance of $\geq 1$.

For the main experiments, the effect of selected samples (Table 1) on MCF-7 cells was assessed. In the assays, MCF-7 cells were either incubated with the test sample alone or with the test sample and $1 \mu \mathrm{M}$ of ZEN. Test samples $(200 \mu \mathrm{L})$ diluted to different concentrations were added after the incubation step with assay medium to remove natural oestrogens. After $1 \mathrm{~h}$ of pre-incubation with the test samples, $100 \mu \mathrm{L}$ ZEN working solution was added to the appropriate wells resulting in a final concentration of $1 \mu \mathrm{M}$. Cells in blanc assay medium served as cell control. Cells incubated with $1 \mu \mathrm{M}$ of ZEN were defined as ZEN control for the co-incubation experiments. 


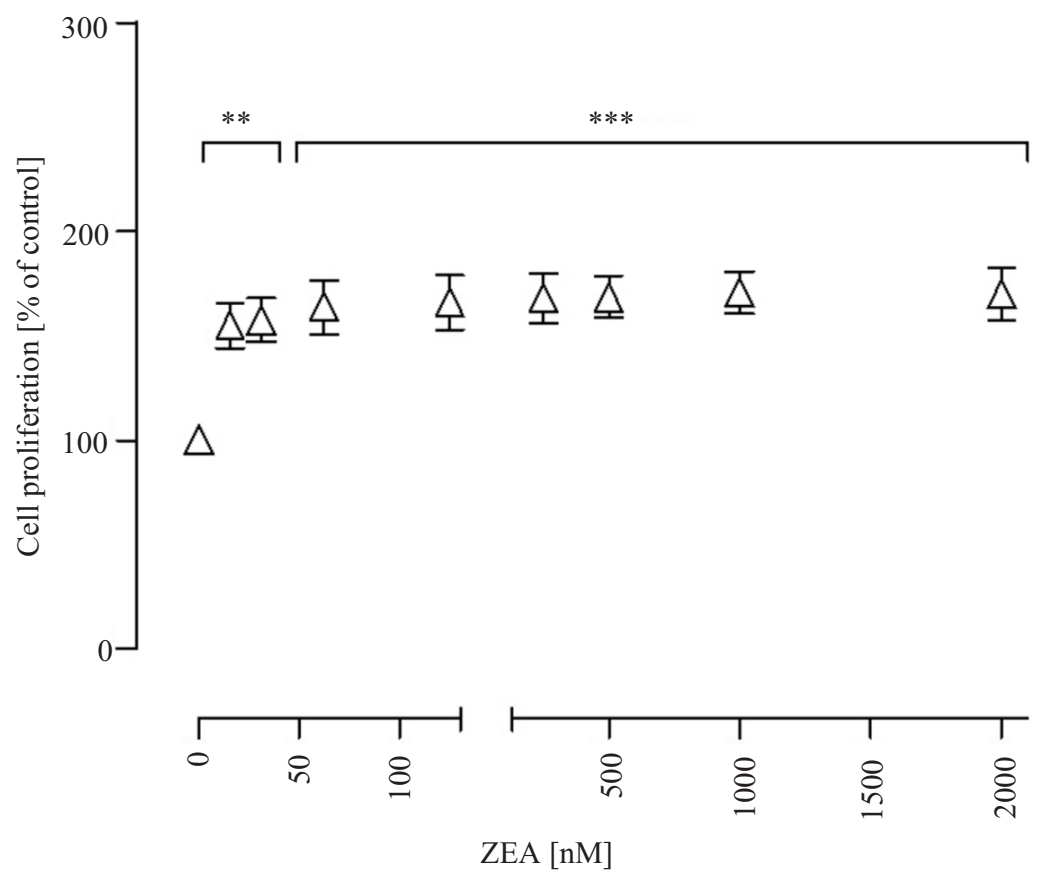

Fig. 1. Proliferation of MCF-7 cells incubated with zearalenone (ZEN; $n=6)$. Data represent means \pm standard deviation. ** $\mathrm{p} \leq 0.01,{ }^{* * *} \mathrm{p} \leq 0.001$ vs. cell control.

\section{Evaluation}

The absorbance was corrected for the optical density of the plates measured directly after the addition of the WST-1 dye. Cell proliferation [\%] in relation to the cell control was calculated using Equation 1.

Cell proliferation $[\%]=\frac{\mathrm{A}_{450 \mathrm{~nm}} \text { value of sample }}{\mathrm{A}_{450 \mathrm{~nm}} \text { value of cell control }} \times 100$

The mean value of the cell proliferation was determined for each independent experiment. The results represent mean values \pm standard deviation (SD) from at least three independent experiments and were plotted using GraphPad Prism version 5.00 for Windows (GraphPad Software, La Jolla California USA).

\section{Statistics}

Differences between the cell control and cells treated with the test substance alone (marked with *) and differences between the ZEN control and the co-incubated samples (marked with ${ }^{\circ}$ ) were determined using IBM $^{\circledast}$ SPSS $^{\circledast}$ Statistics statistical analysis software (Version 19; IBM Corp., USA). Data was analysed for normality using the Shapiro-Wilk test and for homogeneity using the Levene's test.
Normally distributed data were assessed by one-way ANOVA and the posteriori Dunnett's test (equal variance) or the Dunnett T3 test (unequal variance). Nonparametric data were assessed using the Kruskal-Wallis test.

\section{Results}

\section{Oestrogenic effect of ZEN on MCF-7 cell proliferation}

In an initial experiment, the effect of ZEN on MCF-7 cell proliferation was studied to define the working concentration of ZEN for the co-incubation experiments. ZEN increased the cell proliferation already significantly at the lowest concentrations tested (15.6 and $31.3 \mathrm{nM}$ ) up to $157 \%$. Only a minor increase was observed at concentrations above $50 \mathrm{nM}$ (cell proliferation up to 170\%) (Fig. 1). From these results, we selected $1000 \mathrm{nM}(1 \mu \mathrm{M})$ as a working concentration for the co-incubation experiments.

\section{Effects of plant-derived oestrogenic substances on MCF-7 cell proliferation}

The flavonoid 8-PN significantly increased cell proliferation at all tested concentrations, with a maximum of $167 \%$ observed at the highest tested concen- 
(A)

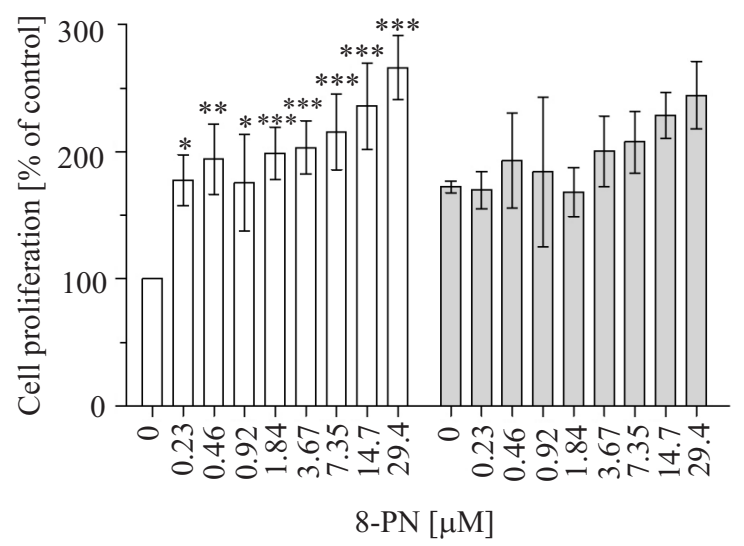

(C)

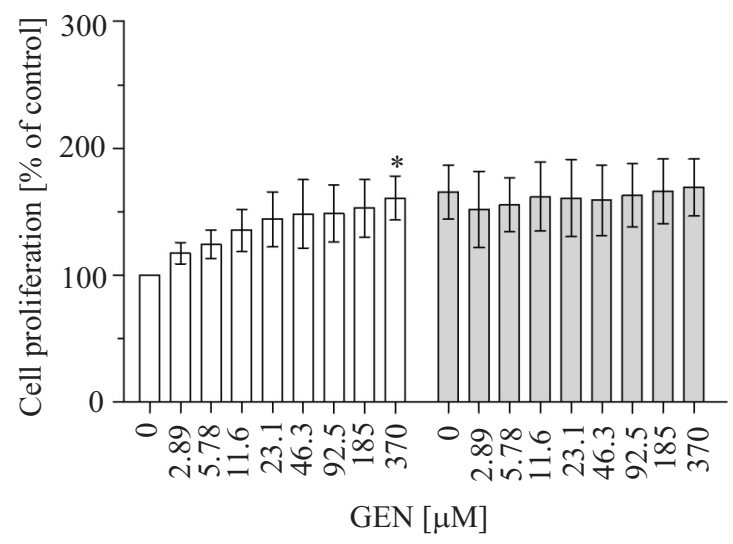

(E)

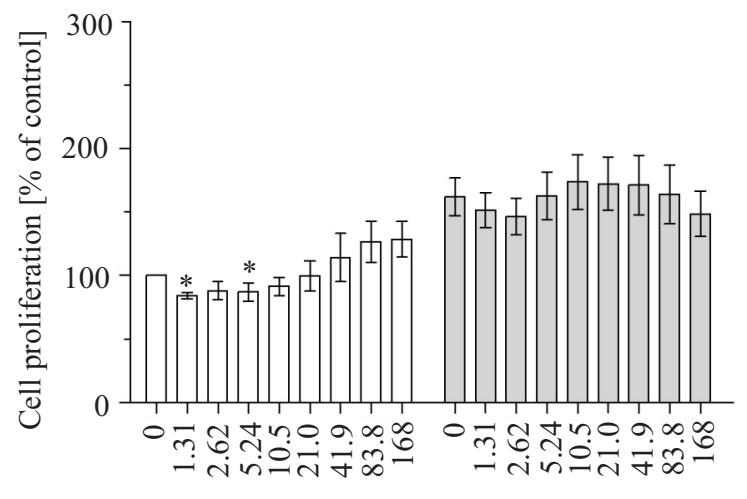

(B)

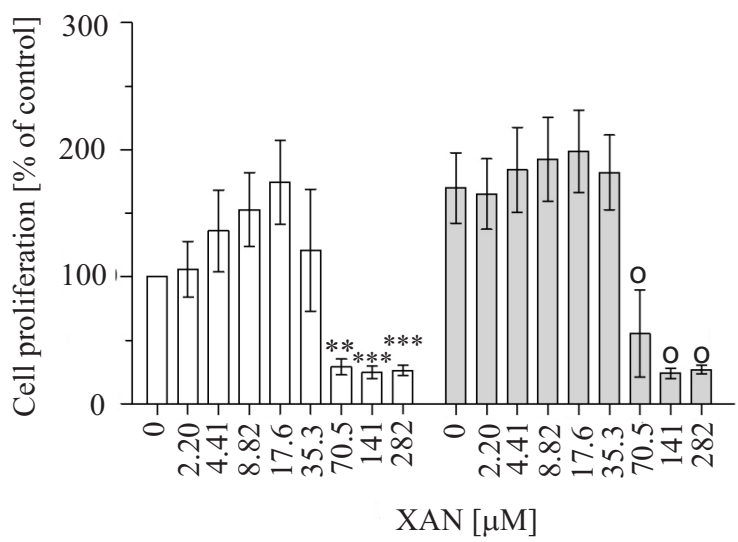

(D)

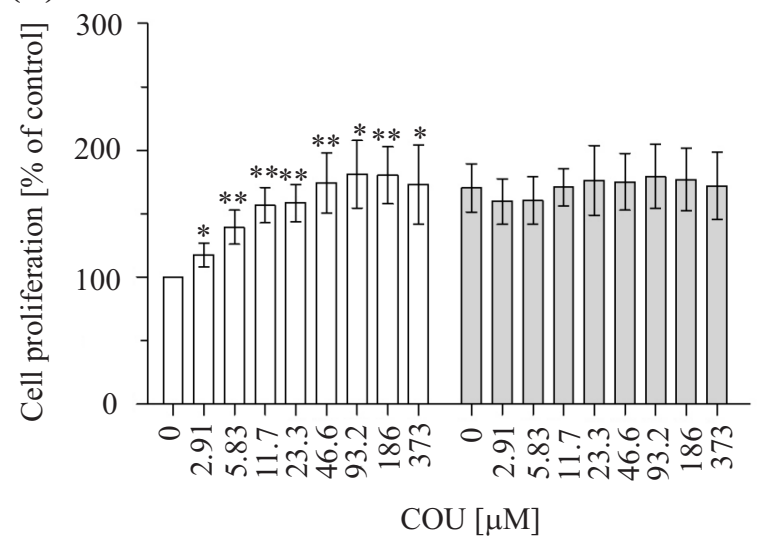

ENT $[\mu \mathrm{M}]$

Fig. 2. Proliferation of MCF-7 cells incubated with plant-derived oestrogenic substances alone (white bars) and in co-incubation with zearalenone (ZEN; grey bars): (A) 8-prenylnaringenin (8-PN; $n=3),(B)$ xanthohumol (XAN; $n=4)$, (C) genistein (GEN; $n=5),(D)$ coumestrol (COU; $n=6)$, and $(E)$ enterolactone $(E N T ; n=5)$. Data represent means \pm standard deviation. * $p \leq 0.05$, ${ }^{* *} \mathrm{p} \leq 0.01,{ }^{* * *} \mathrm{p} \leq 0.001$ vs. cell control; ${ }^{\circ} \mathrm{p} \leq 0.05$ vs. ZEN control.

tration of $29.4 \mu \mathrm{M}$ (Fig. 2A). When co-incubated with ZEN, the dose response curve was less steep and only an increase of up to $72 \%$ in cell proliferation rate compared to the ZEN control was observed. XAN increased cell proliferation concentration-dependently up to a concentration of $17.6 \mu \mathrm{M}$. At higher concentration a clear decline of cell viability was observed.
The same biphasic effect was observed when cells were co-incubated with ZEN (Fig. 2B). GEN caused a concentration-dependent increase in cell proliferation (up to 64\%), but the effect was only significant at the highest tested concentration $(370 \mu \mathrm{M}$; Fig. $2 \mathrm{C})$ when compared to the untreated controls. GEN had no significant effect on cell proliferation when 
co-incubated with ZEN (Fig. 2C). Incubation with COU caused a significant increase $(39-81 \%)$ in the cell proliferation rate at concentrations between 5.83-373 $\mu \mathrm{M}$, but did not significantly affect proliferation of cells co-incubated with ZEN (Fig. 2D). The lignan ENT inhibited cell proliferation at $1.31(16 \%)$ and $5.24 \mu \mathrm{M}(13 \%)$, whereas higher concentrations $(41.9-168 \mu \mathrm{M})$ increased cell proliferation by up to $29 \%$. However, this increasing effect was not significant. Co-incubation of cells with ENT and ZEN did not significantly affect cell proliferation (Fig. 2E). Ranking the substances according to the lowest concentration showing a clear proliferative effect leads to the following order: 8-PN $(0.23 \mu \mathrm{M} ; 78 \%), \mathrm{COU}(5.83$ $\mu \mathrm{M} ; 39 \%)$, GEN (370 $\mu \mathrm{M} ; 61 \%)$.

\section{Discussion}

Using a modified version of the common E-screen assay, plant-derived substances, previously described as exerting oestrogenic effects, were tested for their proliferative or anti-proliferative effect on MCF-7 cells. The samples were additionally tested for their ability to decrease or increase ZEN-induced cell proliferation in co-incubation experiments.

In a preliminary experiment, the working concentration of ZEN for the co-incubation experiments was established. Results show a non-linear dose-response curve. A significant increase in cell proliferation rate (up to 157\%) was already achieved at the lower concentration range (15.6 and $31.3 \mathrm{nM}$ ), which is only slightly below the maximum proliferation rate of $170 \%$ achieved at higher concentrations. These results are in line with findings from $\mathrm{Yu}$ et al. (2005) describing, at concentrations of 32 and $96 \mathrm{nM}$, a significantly increased proliferation of MCF-7 cells by $154.5 \%$ and $190.4 \%$, respectively, compared to the control. The minor differences between these studies might be explained by different assay set-ups (e.g. seeding density, incubation time, cell viability/proliferation assay). However, despite the response of low ZEN concentrations, we decided to use a concentration of $1000 \mathrm{nM}(1 \mu \mathrm{M})$ for the co-incubations with phytoestrogens to ensure significant cell proliferation.

In the main set of experiments, the plant-derived oestrogenic substances 8-PN, XAN, GEN, COU, and ENT were tested alone or in combination with ZEN. The hop flavonoid 8-PN caused the highest increase in MCF-7 cell proliferation at all tested concentrations. Comparable effects of 8-PN have been described in previous studies (Lust et al. 2005, Vanhoecke et al. 2005, Zanoli and Zavatti 2008). However, Brunelli et al. (2009) reported that this compound also exerts cytotoxic effects on MCF-7 cells when used at concentrations above $1 \mu \mathrm{M}$, which differs from our results. The different results might be explained by differing methods (transfected MCF-7 cells, incubation time, and viability tests). In the co-incubation experiments with ZEN, the combined dose-response curve was much less steep, pointing towards an interference of ZEN with the 8-PN induced proliferation. Despite the high concentration of ZEN, cell proliferation was increased when cells were co-incubated with 8-PN at the highest concentrations (14.7 and $29.4 \mu \mathrm{M}$ ) compared to the ZEN control. Another hop flavonoid, XAN, was shown to have anti-oestrogenic activity in Ishikawa cells, a human endometrial adenocarcinoma cell line (Gerhauser et al. 2002). In the present study, XAN inhibited cell proliferation at higher concentrations, indicating a loss of viability. No major differences between incubations with XAN alone or co-incubations with ZEN were observed. Cytotoxic effects have already been reported for 50 and $100 \mu \mathrm{M}$ XAN, which is in line with the present observations (Monteiro et al. 2008). Other studies have shown that the flavonoid GEN can have a biphasic effect on the growth of MCF-7 cells: concentrations as low as $10 \mathrm{nM}$ increased the proliferation rate of MCF-7 cells, but high concentrations (above 10-20 $\mu \mathrm{M}$ ) inhibited cell proliferation (Wang et al. 1996, Hsieh et al. 1998). In a more recent study, it was shown that GEN (16 and $32 \mu \mathrm{M}$ ) reduced the cell viability of MCF-7 cells induced by 10 and $20 \mathrm{nM}$ ZEN (Wang et al. 2010). In the current experiments, the cell proliferation was not increased significantly in the co-incubation experiments with GEN and ZEN. GEN alone increased the cell proliferation only in the highest tested concentration of $370 \mu \mathrm{M}$ significantly. Our study showed no significant decrease of MCF-7 cell proliferation in the co-incubation experiments. This might be due to the higher ZEN concentration that we used $(1 \mu \mathrm{M})$. COU is considered to be one of the most potent phytoestrogens. It exhibits strong oestrogenic activity on ER $\alpha$, but an up to 100 -fold stronger activation of ER $\beta$ (Kuiper et al. 1998, Schmitt and Stopper 2001, Harris et al. 2005). In the present study, COU showed a more pronounced proliferative effect on MCF-7 cells than GEN, which was also reported by Sakomoto et al. (2010). ENT at 1.31 and $5.24 \mu \mathrm{M}$ showed a slight inhibitory effect at low concentrations, both in incubations with GEN alone and in the co-incubation experiments with ZEN, which remains unexplained. In previous studies, ENT increased MCF-7 cell proliferation at concentrations between 1-10 $\mu \mathrm{M}$, and inhibited cell proliferation above $10 \mu \mathrm{M}$ (Mousavi and Adlercreutz 1992). Another study has shown that concentrations of 0.5 and $1 \mu \mathrm{M}$ ENT significantly decreased MCF-7 cell viability (Abarzua et al. 2012). Mousavi and Adlercreutz (1992) showed that ENT 
inhibited the proliferative effect of E2 on MCF-7 cells. In contrast, ENT was not able to significantly reduce the ZEN-induced proliferation of MCF-7 cells in the present study.

The plant-derived substances were selected based on their ability to bind to ER $\alpha$ and/or ER $\beta$ (8-PN, GEN, COU) or to inhibit the proliferation of cancer cells (XAN, ENT). Despite this, there was no evidence that any of the tested compounds were able to significantly reduce the $\mathrm{ZEN}$-induced proliferation and hence the pro-oestrogenic effect of ZEN. However, as it has been shown previously that at least some of the tested compounds inhibit the oestrogen-induced growth of cancer cells, it cannot be excluded that the selected concentration of ZEN $(1 \mu \mathrm{M})$ was too high to detect an anti-oestrogenic effect in the current assay. Further studies devoted to the potential interactions between myco- and phytoestrogens should include a broader concentration range of ZEN and also its metabolites, as some of these have an even higher oestrogenic activity (EFSA 2016).

\section{Acknowledgements}

This work was supported by the Austrian Research Promotion Agency under Grant 828013. We thank Ryan Hines for proofreading.

\section{References}

Abarzua S, Serikawa T, Szewczyk M, Richter DU, Piechulla B, Briese V (2012) Antiproliferative activity of lignans against the breast carcinoma cell lines MCF 7 and BT 20 . Arch Gynecol Obstet 285: 1145-1151.

Adams NR (1995) Detection of the effects of phytoestrogens on sheep and cattle. J Anim Sci 73: 1509-1515.

Bergman Jungeström M, Thompson LU, Dabrosin C (2007) Flaxseed and its lignans inhibit estradiol-induced growth, angiogenesis, and secretion of vascular endothelial growth factor in human breast cancer xenografts in vivo. Clin Cancer Res 13: 1061-1067.

Blanquer-Rossello MM, Oliver J, Valle A, Roca P (2013) Effect of xanthohumol and 8-prenylnaringenin on MCF-7 breast cancer cells oxidative stress and mitochondrial complexes expression. J Cell Biochem 114: 2785-2794.

Brunelli E, Pinton G, Chianale F, Graziani A, Appendino G, Moro L (2009) 8-Prenylnaringenin inhibits epidermal growth factor-induced MCF-7 breast cancer cell proliferation by targeting phosphatidylinositol-3-OH kinase activity. J Steroid Biochem Mol Biol 113: 163-170.

Brzozowski AM, Pike AC, Dauter Z, Hubbard RE, Bonn T, Engstrom O, Ohman L, Greene GL, Gustafsson JA, Carlquist M (1997) Molecular basis of agonism and antagonism in the oestrogen receptor. Nature 389: 753-758.

Busch C, Noor S, Leischner C, Burkard M, Lauer UM, Venturelli $S$ (2015) Anti-proliferative activity of hop-derived prenylflavonoids against human cancer cell lines. Wien Med Wochenschr 165: 258-261.

Danciu C, Soica C, Csanyi E, Ambrus R, Feflea S, Peev C, Dehelean $C$ (2012) Changes in the anti-inflammatory activity of soy isoflavonoid genistein versus genistein incorporated in two types of cyclodextrin derivatives. Chem Cent J 6: 58 .

Deeb D, Gao X, Jiang H, Arbab AS, Dulchavsky SA, Gautam SC (2010) Growth inhibitory and apoptosis-inducing effects of xanthohumol, a prenylated chalone present in hops, in human prostate cancer cells. Anticancer Res 30: 3333-3339.

Döll S, Dänicke S (2011) The Fusarium toxins deoxynivalenol (DON) and zearalenone (ZON) in animal feeding. Prev Vet Med 102: 132-145.

European Food Safety Authority (EFSA) (2011) Scientific Opinion on the risks for public health related to the presence of zearalenone in food. EFSA J 9: 1-124.

European Food Safety Authority (EFSA) (2016) Appropriateness to set a group health-based guidance value for zearalenone and its modified forms. EFSA J 14: 1-46.

Fink-Gremmels J, Malekinejad H (2007) Clinical effects and biochemical mechanisms associated with exposure to the mycoestrogen zearalenone. Anim Feed Sci Tech 137: 326-341.

Gajecka M, Rybarczyk L, Jakimiuk E, Zielonka L, Obremski K, Zwierzchowski W, Gajecki M (2012) The effect of experimental long-term exposure to low-dose zearalenone on uterine histology in sexually immature gilts. Exp Toxicol Pathol 64: 537-542.

Gajecki M (2002) Zearalenone-undesirable substances in feed. Pol J Vet Sci 5: 117-122.

Gerhauser C, Alt A, Heiss E, Gamal-Eldeen A, Klimo K, Knauft J, Neumann I, Scherf HR, Frank N, Bartsch H, Becker H (2002) Cancer chemopreventive activity of Xanthohumol, a natural product derived from hop. Mol Cancer Ther 1: 959-969.

Harris DM, Besselink E, Henning SM, Go VL, Heber $\mathrm{D}$ (2005) Phytoestrogens induce differential estrogen receptor $\alpha$ - or $\beta$-mediated responses in transfected breast cancer cells. Exp Biol Med (Maywood) 230: 558-568.

Hilakivi-Clarke L, Cabanes A, Olivo S, Kerr L, Bouker KB, Clarke R (2002) Do estrogens always increase breast cancer risk? J Steroid Biochem Mol Biol 80: 163-174.

Hsieh CY, Santell RC, Haslam SZ, Helferich WG (1998) Estrogenic effects of genistein on the growth of estrogen receptor-positive human breast cancer (MCF-7) cells in vitro and in vivo. Cancer Res 58: 3833-3838.

Jungbauer A, Medjakovic S (2014) Phytoestrogens and the metabolic syndrome. J Steroid Biochem Mol Biol 139: 277-289.

Kuiper-Goodman T, Scott PM, Watanabe H (1987) Risk assessment of the mycotoxin zearalenone. Regul Toxicol Pharmacol 7: 253-306.

Kuiper GG, Lemmen JG, Carlsson B, Corton JC, Safe SH, van der Saag PT, van der Burg B, Gustafsson JA (1998) Interaction of estrogenic chemicals and phytoestrogens with estrogen receptor $\beta$. Endocrinology 139: 4252-4263.

Kurzer MS, Xu X (1997) Dietary phytoestrogens. Annu Rev Nutr 17: 353-381.

Leclercq G, Jacquot Y (2014) Interactions of isoflavones and other plant derived estrogens with estrogen receptors for prevention and treatment of breast cancer-consider- 
ations concerning related efficacy and safety. J Steroid Biochem Mol Biol 139: 237-244.

Lindberg MK, Moverare S, Skrtic S, Gao H, Dahlman-Wright K, Gustafsson JA, Ohlsson C (2003) Estrogen receptor (ER)- $\beta$ reduces ER $\alpha$-regulated gene transcription, supporting a "ying yang" relationship between ER $\alpha$ and ER $\beta$ in mice. Mol Endocrinol 17: 203-208.

Lust S, Vanhoecke B, Janssens A, Philippe J, Bracke M, Offner F (2005) Xanthohumol kills B-chronic lymphocytic leukemia cells by an apoptotic mechanism. Mol Nutr Food Res 49: 844-850.

Malekinejad H, Schoevers EJ, Daemen IJ, Zijlstra C, Colenbrander B, Fink-Gremmels J, Roelen BA (2007) Exposure of oocytes to the Fusarium toxins zearalenone and deoxynivalenol causes aneuploidy and abnormal embryo development in pigs. Biol Reprod 77: 840-847.

Matsumura A, Ghosh A, Pope GS, Darbre PD (2005) Comparative study of oestrogenic properties of eight phytoestrogens in MCF7 human breast cancer cells. J Steroid Biochem Mol Biol 94: 431-443.

Matthews J, Gustafsson JA (2003) Estrogen signaling: a subtle balance between ER $\alpha$ and ER $\beta$. Mol Interv 3: 281-292.

Milligan S, Kalita J, Pocock V, Heyerick A, De Cooman L, Rong H, De Keukeleire D (2002) Oestrogenic activity of the hop phyto-oestrogen, 8-prenylnaringenin. Reproduction 123: 235-242.

Minervini F, Dell'Aquila ME (2008) Zearalenone and reproductive function in farm animals. Int J Mol Sci 9: 2570-2584.

Monteiro R, Calhau C, Silva AO, Pinheiro-Silva S, Guerreiro S, Gartner F, Azevedo I, Soares R (2008) Xanthohumol inhibits inflammatory factor production and angiogenesis in breast cancer xenografts. $\mathrm{J}$ Cell Biochem 104: 1699-1707.

Mousavi Y, Adlercreutz H (1992) Enterolactone and estradiol inhibit each other's proliferative effect on MCF-7 breast cancer cells in culture. J Steroid Biochem Mol Biol 41: 615-619.

Mueller SO, Simon S, Chae K, Metzler M, Korach KS (2004) Phytoestrogens and their human metabolites show distinct agonistic and antagonistic properties on estrogen receptor $\alpha(E R \alpha)$ and ER $\beta$ in human cells. Toxicol Sci 80: 14-25.

Nadal-Serrano M, Pons DG, Sastre-Serra J, Blanquer-Rossello Mdel M, Roca P, Oliver J (2013) Genistein modulates oxidative stress in breast cancer cell lines according to $E R \alpha / E R \beta$ ratio: effects on mitochondrial functionality, sirtuins, uncoupling protein 2 and antioxidant enzymes. Int J Biochem Cell Biol 45: 2045-2051.

Nikov GN, Hopkins NE, Boue S, Alworth WL (2000) Interactions of dietary estrogens with human estrogen receptors and the effect on estrogen receptor-estrogen response element complex formation. Environ Health Perspect 108: 867-872.

Paruthiyil S, Cvoro A, Tagliaferri M, Cohen I, Shtivelman E, Leitman DC (2011) Estrogen receptor $\beta$ causes a G2 cell cycle arrest by inhibiting CDK1 activity through the regulation of cyclin B1, GADD45A, and BTG2. Breast Cancer Res Treat 129: 777-784.

Pearce ST, Jordan VC (2004) The biological role of estrogen receptors $\alpha$ and $\beta$ in cancer. Crit Rev Oncol Hematol 50: 3-22.

Ramanathan L, Gray WG (2003) Identification and characterization of a phytoestrogen-specific gene from the
MCF-7 human breast cancer cell. Toxicol Appl Pharmacol 191: 107-117.

Record IR, Dreosti IE, McInerney JK (1995) The antioxidant activity of genistein in vitro. $\mathrm{J}$ Nutr Biochem 6: 481-485.

Rietjens IM, Sotoca AM, Vervoort J, Louisse J (2013) Mechanisms underlying the dualistic mode of action of major soy isoflavones in relation to cell proliferation and cancer risks. Mol Nutr Food Res 57: 100-113.

Russo M, Russo GL, Daglia M, Kasi PD, Ravi S, Nabavi SF, Nabavi SM (2016) Understanding genistein in cancer: The "good" and the "bad" effects: A review. Food Chem 196: 589-600.

Sakamoto T, Horiguchi H, Oguma E, Kayama F (2010) Effects of diverse dietary phytoestrogens on cell growth, cell cycle and apoptosis in estrogen-receptor-positive breast cancer cells. J Nutr Biochem 21: 856-864.

Schatzmayr G, Streit E (2013) Global occurrence of mycotoxins in the food and feed chain: facts and figures. World Mycotoxin J 6: 213-222.

Schmitt E, Stopper H (2001) Estrogenic activity of naturally occurring anthocyanidins. Nutr Cancer 41: 145-149.

Schoevers EJ, Santos RR, Colenbrander B, Fink-Gremmels J, Roelen BA (2012) Transgenerational toxicity of Zearalenone in pigs. Reprod Toxicol 34: 110-119.

Soto AM, Lin TM, Justicia H, Silvia RM, Sonnennschein C (1992) An "in culture" bioassay to assess the estrogenicity of xenobiotics (E-screen). In: Colborn $\mathrm{T}$, Clement C (eds) Chemically Induced Alterations in Sexual Development: the Wildlife/Human Connection. Princeton Scientific Publishing, Princeton, New Jersey, USA, pp 295-309

Tiemann U, Danicke S (2007) In vivo and in vitro effects of the mycotoxins zearalenone and deoxynivalenol on different non-reproductive and reproductive organs in female pigs: a review. Food Addit Contam 24: 306-314.

Urry WH, Wehrmeister HL, Hodge EB, Hidy PH (1966) The structure of zearalenone. Tetrahedron Lett 7: 3109-3114.

Vanhoecke B, Derycke L, Van Marck V, Depypere H, De Keukeleire D, Bracke M (2005) Antiinvasive effect of xanthohumol, a prenylated chalcone present in hops $(\mathrm{Hu}$ mulus lupulus L.) and beer. Int J Cancer 117: 889-895.

Wang D, Ma Q, Zhang N, Qi D (2010) Genistein inhibit the proliferation induced by zearalenone in MCF-7 cells. Mol Cell Toxicol 6: 25-31.

Wang TT, Sathyamoorthy N, Phang JM (1996) Molecular effects of genistein on estrogen receptor mediated pathways. Carcinogenesis 17: 271-275.

Yoshimaru T, Komatsu M, Tashiro E, Imoto M, Osada H, Miyoshi Y, Honda J, Sasa M, Katagiri T (2014) Xanthohumol suppresses oestrogen-signalling in breast cancer through the inhibition of BIG3-PHB2 interactions. Sci Rep 4: 7355 .

Yu Z, Zhang L, Wu D, Liu F (2005) Anti-apoptotic action of zearalenone in MCF-7 cells. Ecotoxicol Environ Saf 62: 441-446.

Zanoli P, Zavatti M (2008) Pharmacognostic and pharmacological profile of Humulus lupulus L. J Ethnopharmacol 116: 383-396.

Zinedine A, Soriano JM, Molto JC, Manes J (2007) Review on the toxicity, occurrence, metabolism, detoxification, regulations and intake of zearalenone: an oestrogenic mycotoxin. Food Chem Toxicol 45: 1-18. 